\title{
Reflections from the Dean, Faculty of Education, Brock University
}

\section{Michael Manley-Casimir}

The opportunity to contribute an editorial to the founding issue of Teaching and Learning is a privilege and I would like to begin by commending Dr. Ray Chodzinski, Associate Dean, Hamilton Campus for his vision, his energy and initiative in bringing this publication to fruition. The topic is acutely appropriate at this time in Ontario with the provincial government's decision to impose its teacher testing initiative on the teachers of the province.

Suffice it to note that the widespread opposition to the three pronged initiative is not at all surprising; The Entry to the Profession Test, the proposed Recertification process and the Performance Assessment component combine to undermine the role of provisionally accredited Faculties of Education to establish and maintain appropriate standards of public and professional accountability, to reduce if not vitiate the role of the Ontario College of Teachers as a professional college overseeing and monitoring the profession, and to subvert entirely the legitimate aspirations of many teachers, their affiliates as well as the Ontario Teachers Federation and the Ontario Secondary School Teachers Association whose mandate is to preserve and enhance the professional status of teachers in Ontario. There is no question in my mind, writing from a strictly personal point of view, that the teacher testing initiative will prove to be a costly failure and, as is already evident, will generate system wide opposition and damage the occupation of teaching through a process of government ordained deprofessionalization.

What the provincial government should have done, in my view, was to charge the Ontario College of Teachers with the responsibility for developing and administering an appropriate Entry to the Profession Test and for developing policy guidelines to ensure the continuous professional development of teachers, and to require and fund school boards to institute a first year, probationary induction program for beginning teachers, perhaps in collaboration with Faculties of Education, followed by a more stringent and rigorous performance appraisal process conducted by building principals and consistent with the principles of natural justice.

Such initiatives would have appropriately protected the public interest in publically funded education, charged the Ontario College of Teachers with responsibilities appropriate to its mandate and placed the responsibility for the induction and performance appraisal of beginning teachers where it correctly belongs-with the school boards and building principals.

It is really quite tragic to watch poor educational policy being forced down the throats of talented and committed teachers in Ontario. If politicians in Queen's Park had spent any time at all in schools working with classroom teachers, listening to their concerns, appreciating the endless hours of their personal time they commit to working with children and young people, they might have been more aware of the real issues facing teachers in the classroom. Over the past two decades the task of teaching has become increasingly demanding as the school has assumed the roles historically played by churches, social agencies, and to some extent by families themselves. Expected to prepare young people to function effectively in the next economy and build useful and productive lives, teach the intellectual and vocational understandings necessary for such endeavors, teachers need support in developing a truly professional status in this province. Instead they are systematically demoralized by the continuing attacks by government on their competence and commitment. What teachers need is help and assistance to do better the job they already do well-to work with the young people of Ontario in building a future for all.

Instead of initiating a Teacher Testing Initiative that demoralizes and deprofessionalizes teachers and teaching, I hope the next Minister of Education will start supporting teachers by appreciating the real work they really do and putting in place sensible educational policies designed to assure teachers of government support and the public that teachers are not here to be shellacked and abused but supported and respected.

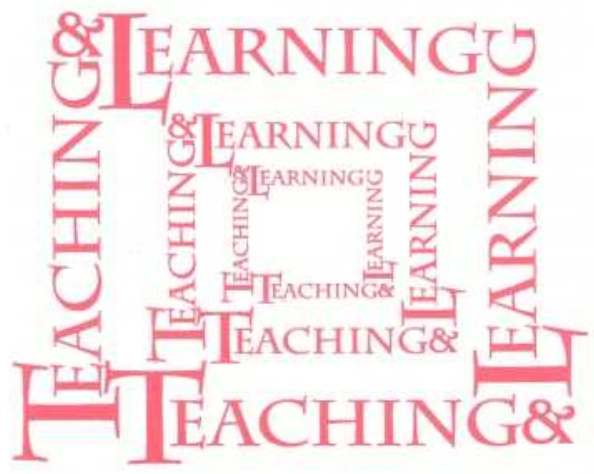

